\title{
PROBLEMS EXPERIENCED BY CHILDREN WITH A SIBLING WITH DOWN SYNDROME
}

\author{
Burcu Aktaş ${ }^{1 \mathrm{i}}$ \\ Mehtap Kot ${ }^{2}$ \\ İlknur Çifci-Tekinarslan ${ }^{3}$ \\ ${ }^{1}$ Research Assistant, \\ Bolu Abant Izzet Baysal University, \\ Faculty of Education, \\ Turkey \\ orcid.org/0000-0003-4421-9891 \\ ${ }^{2}$ Assistant Professor, \\ Inonü University, \\ Faculty of Education, \\ Turkey \\ orcid.org/0000-0002-1085-0645 \\ 3Professor, \\ Bolu Abant Izzet Baysal University, \\ Faculty of Education, \\ Turkey \\ orcid.org/0000-0001-5028-3289
}

\begin{abstract}
:
This research aims to identify the problems of normally developing siblings of children with Down syndrome. The participants of the study consisted of 11 typically developing siblings between the ages of 8-19 who had a sibling with Down syndrome. This study was designed according to a qualitative research methods. A semi-structured interview technique was used to gather research data. Descriptive analysis was used in the analysis of the data. Considering the problems experienced by children with typical development who have a sibling with Down syndrome; in the home environment, that they have problems in the common use of their products, that their siblings with Down's syndrome do not violate them, and that their parents - especially their mothers - are more interested in siblings with Down's syndrome; that in the school environment your siblings are deterred from studying and that they mock the other children's brothers; in social life, the siblings with Down's syndrome had problems in the regular games, so they said that they had no friends and that the other children were ridiculing their siblings with Down's syndrome.
\end{abstract}

Keywords: Down syndrome, sibling, problems experienced by siblings

${ }^{i}$ Correspondence: email burcuaktas@ibu.edu.tr 


\section{Introduction}

The participation of a new individual in the family is always happy. But the participation of a child with special needs in the family leads to confusion, disappointment, and the start of a difficult process (Esenay \& Yiğit, 2018; Kaya, Özel \& Yiğit, 2020). Having a child with special needs is a condition that pretty much affects parents. Parents usually experience feelings of shock, denial, guilt, and acceptance when they learn that they have a child who develops differently (Ataman, 2003; M.E.B., 2006). These changes in the family affect siblings as well as parents (Aksoy \& Berçin-Yıldırım, 2008; Içöz, 2001). Because siblings play significant roles and models in each other's lives (Gözün-Kahraman \& Soylu-Karaday1, 2015), they are the most important peers who provide a suitable environment for each other to realize social interactions and share feelings of love and trust (Yavuzer, 2001). At the same time, the interaction between siblings also affects their future social relationships, personality development, and the way they deal with various problem situations (Hughes, Mcharg \& White, 2018).

Having a child with special needs in the family affects the emotional and psychosocial situation of the children in the family (Gözün-Kahraman \& Soylu-Karadayı, 2015; Konuk \& Yildırım-Doğru, 2012). This circumstance also affects the relations between siblings. According to the researches, the mood changes and the processes experienced by a typically developing child with a sibling with special needs; the family's attitude towards the typically developing sibling (Aksoy \& Berçin-Yıldırım, 2008; Seligman, 1983) and their children with special needs (İçmeli, Ataoğlu, Canan, \& Özçetin, 2008; Kaminsky \& Dewey, 2001; Kurnoff, 2008; Ünal \& Baran, 2011) is directly related. Typically developing children with siblings with special needs both try to understand the inadequacy of their siblings and have more responsibility than their peers (Ünal \& Baran, 2011). In addition, siblings with typical development experience the feeling that their families are more interested in their children with special needs (Şenel, 1995), which negatively affects the relations between siblings. According to research, typical developing children with a sibling with special needs should be informed about their sibling's condition so that they can have a more positive relationship with their siblings and help their siblings (Girli, 1995; Gözün-Kahraman \& Soylu-Karadayı, 2015; Konuk \& Yıldırım-Doğru, 2012; Küçüker, 1997; Ünal, 2009).

The inability to understand the disability physically negatively affects the coping process of the normally developing child with a sibling with special needs (Girli, 1995; Şengül-Erdem \& Fazlığlu, 2020). According to the research findings of GözünKahraman and Soylu-Karadayı (2015), most of the children with typical development (10 out of 14) stated that they have a negative attitude towards other people's approach to their siblings with special needs. In the research, it has been stated that $70 \%$ of the children who get negative reactions from other people are children with physical and physical disabilities. This situation makes us think that the physical image is effective against the manner of society in terms of disabled people. It can be said that having a sibling with Down Syndrome (DS) affects the relations between siblings and is a troublesome process for normally developing siblings. There are studies on how the 
quality of sibling relationships will be affected if one of the siblings has DS. One of these studies; was conducted by Kaminsky and Dewey (2001). Kaminsky and Dewey (2001) in their work they compared the sibling relationships of children with Autism Spectrum Disorder (ASD), DS and typically development. As a result of the research, it was found that siblings of children with ASD and DS appreciated their siblings more and discussed less in their relationships than typically children compared. Fisman, Wolf, Ellison, and Freeman, (2000) compared the siblings of children with ASD with the siblings of children with DS and stated that internalizing behavioral problems are higher in children with siblings with ASD.

Various studies have been conducted examining the sibling relationships of children with special needs in Turkey. Among these studies, the characteristics of the typically developing siblings (Eyüboğlu, Baykara, \& Eyüboğlu, 2017; Şengül-Erdem \& Fazlıoğlu, 2020), the anxiety levels of the siblings (Girli, 1995; Şenel, 1995), the attitudes of the siblings towards their special needs siblings (Küçüker, 1997; Atasoy, 2002; Şafak, Eldeniz-Çetin, \& Kot, 2014), sibling relationships (Atasoy, 2002; Ahmetoğlu, 2004; Zoylan, 2005; Aksoy \& Berçin-Yıldırım, 2008; Ünal \& Baran, 2012; Özen-Çınar, Kartal \& Korkmaz -Aslan, 2015; Kizilalp, 2018, Sınanmış \& Kolburan, 2019; Yersel, Durualp, \& Baran, 2019; Şengül-Erdem \& Fazlıoğlu, 2020), the problems experienced by siblings (Kalecik, 2013), the siblings' acceptance of their special needs siblings (Girli, 1995), the effect of informing siblings about their siblings with special needs (Küçüker, 1997; Konuk \& Yıldırım-Doğru, 2012) and the experiences of children with siblings with special needs (Gözün-Kahraman \& Soylu-Karaday1, 2015) were found. There are studies in the literature to determine the level of anxiety experienced by their families regarding children with DS (İçöz, \& Baran, 2001; Yukay, 1998). However, no research has been found to directly determine the problems experienced by the siblings of children with DS. In this context, the data obtained from this research is considered important in terms of raising awareness to parents of children with DS about the problems experienced by their children with DS, awareness that they should include their children with typically development in the education of their children with DS and that they should not neglect them. Also, showing that the cooperation of their siblings is important in the problems of their children with DS, providing opportunities for children to understand their feelings and review their child-rearing attitudes.

The purpose of this research; to determine the problems experienced by the typically developing siblings of children with DS. For this purpose, answers to the following questions were sought:

1) What problems do the typically developing siblings of children with DS experience at home?

2) What problems do the typically developing siblings of children with DS experience at school?

3) What are the social problems experienced by the siblings of children with DS who are developing typically? 


\section{Methods}

In this study, it was aimed to determine the problems experienced by typically developing children with siblings with Down syndrome. The case study design, one of the qualitative research methods, was used in the study.

\subsection{Research Model}

In this study, one of the qualitative research methods, the case study design was used. In the case design, the aim is to reveal results regarding a specific situation. Factors related to a situation (environment, individuals, events, processes) are investigated with a holistic approach, and data are collected about how they are affected by the relevant situation and how they affect the situation (Yıldırım \& Şimşek, 2008). The case study is created through an in-depth description and analysis of a limited system (Merriam, 2009).

\subsection{Participants}

The participants of the study consisted of 11 typically developing siblings between the ages of 8-19 who had a sibling with DS who attended support education centers in Bolu. The participants of the study were determined by the criterion sampling method, which is one of the purposive sampling methods. For the research participants, a) Having a sibling with DS was determined as a criterion. The demographic information of the study group of the research is shown in Table 2.1.

Table 2.1: Characteristics of the participants

\begin{tabular}{|c|c|c|c|c|}
\hline & \multicolumn{2}{|c|}{ Sibling with Typically Developing } & \multicolumn{2}{c|}{ Sibling with Down Syndrome } \\
\cline { 2 - 5 } & Age & Gender & Age & Gender \\
\hline P1 & 9 & F & 13 & F \\
\hline P2 & 8 & M & 12 & F \\
\hline P3 & 11 & F & 14 & M \\
\hline P4 & 18 & M & 15 & F \\
\hline P5 & 11 & M & 15 & F \\
\hline P6 & 19 & M & 15 & M \\
\hline P7 & 19 & F & 10 & F \\
\hline P8 & 15 & F & 8 & M \\
\hline P9 & 16 & M & 6 & M \\
\hline P10 & 15 & F & 8 & \\
\hline P11 & 13 & M & & \\
\hline
\end{tabular}

When Table 2.1 is examined, it is seen that 3 of the research participants are older sisters, 4 are older brothers, 2 are sisters and 2 are brothers. The age range of siblings with Down syndrome varies between 6-15, and 6 siblings with Down syndrome are girls and 5 are boys.

\subsection{Data Collection Tool}

In the collection of data, were used from semi-structured interview techniques one of the qualitative data collection techniques. The interview technique was preferred because it 
enters the inner world of individuals and expresses opinions from their perspectives. In the research, interview questions were created based on the literature review and the research purpose. Expert opinion was taken from a person who is an expert in the field of special education regarding the interview questions. Then, a semi-structured interview form was created. All interviews with the participants were conducted by the researcher. Before each interview, the researcher informed the participant about the purpose of the research and answered the questions asked by the participants in line with the purpose of the research. The participants were informed that the interviews would be recorded with a tape recorder and that the recordings would only be listened to by the researchers. During the interviews, the real names of the participants were kept secret and their code names were used. During the interviews, 3 main questions were asked to the participants.

\subsection{Data Analysis}

Descriptive analysis includes summarizing and interpreting the data obtained according to predetermined themes (Yıldırım \& Şimşek, 2005). In descriptive analysis, direct quotations are frequently used in order to express participant views in a striking way. The main purpose of doing descriptive analysis is to convey the findings to the reader in a summarized and interpreted form. For this purpose, first of all, the data obtained are described in a systematic and clear way. Then, these descriptions are explained and interpreted, cause-effect relationships are examined and some conclusions are reached (Yıldırım \& Şimşek, 2005).

After all the interviews were completed, the transcription of the audio recordings was started. During the transcription of the sound recordings, all the spoken words in the sound recording were written as they were without any correction. The pages where the audio recordings were converted into text and each line on the page were numbered. In order to check the accuracy of the transcriptions, the audio recordings were listened to again and the data written at that time was read and it was seen that the data were complete.

\subsubsection{Creating Themes and Codes}

Interview questions were used to create the themes. For example, the theme of "Problems at home" was created for the answers to the question "What are the problems you have at home with your brother with Down syndrome?", which is included in the interview questions. In this way, a total of three themes were obtained:

- Problems at home,

- Problems at school,

- Problems in social life.

After the themes were created, the codes were also created. At this stage, the researcher read the written text of the interview records and created titles. Information on themes and codes is shown in Table 2. 


\begin{tabular}{|l|l|}
\hline \multicolumn{2}{|c}{ Table 2.2: Themes and Codes } \\
\hline Themes & Codes \\
\hline Theme 1: Problems in the home environment & a) Use of objects \\
& b) Violence \\
& c) Neglect \\
d) Inability to meet their needs \\
\hline Theme 2: Problems in the school environment & e) Health problems \\
& f) Future anxiety \\
\hline Theme 3: Problems in social life & a) Inability to study \\
& b) Ridicule \\
\hline
\end{tabular}

\subsection{Validity and Reliability}

In qualitative research, the accuracy of scientific findings is related to "validity", and the repeatability of scientific findings is related to "reliability" (Yıldırım \& Şimşek, 2008). Accordingly, some measures were taken to increase the validity and reliability of the study.

First of all, in order to increase the internal validity (credibility) of the research, while developing the interview questions, a conceptual framework was created by scanning the literature and the themes were studied extensively to cover the relevant concepts in the content analysis. Within the scope of the research, it was tried to ensure that the siblings with normal development could express their views sincerely without any anxiety or fear. The data collected in this way was ensured to reflect the real situation. Another process to increase the external validity (transferability) of the research is to define the research model, study group, data collection tool, data collection process, data analysis and interpretation in detail. In addition, what was done in the process was tried to be explained in detail.

All of the findings were written directly without comment in order to increase the internal reliability (consistency) of the research. In addition, the researcher and a doctoral research assistant in the field of special education independently coded the data obtained during the interview. Then, by comparing the created codes and themes, the reliability calculation was made between the coders. The inter-coder reliability score obtained as a result of the comparison was found as $\% 100$.

Finally, in order to increase the external reliability (verifiability) of the research, the researcher wrote in detail what was done in the process.

\section{Results}

In the study, the data obtained from the semi-structured interviews conducted to determine the problems experienced by the siblings of children with DS with typically development were analyzed with content analysis. As a result of the descriptive analysis, three main themes were reached. The main themes of the research are; 1 ) problems in the home environment, 2) problems in the school environment, 3) problems in social life. 


\subsection{Problems Experienced in the Home Environment}

Problems experienced by children with typically development with siblings with DS in the home environment; a) use of objects, b) violence, c) neglect, d) inability to meet their needs, e) health problems, f) jealousy, g) communication problems were collected in seven sub-themes.

\subsubsection{Use of Objects}

Typically developing children with siblings with DS stated that they had problems in sharing some belongings with their siblings with DS. It has been stated that the sibling with DS does not want to share with the typically developing sibling in the use of devices such as mobile phones, computers, and televisions and always wants these devices to be under his control (P1, P2, P3, P5). Participant 1's opinion on the situation is that; "He does not leave the TV remote or the computer. I always have to watch the cartoons he wants." Participant 3's view on the situation is that; "My sister received a phone call to let me know about my stay at school. My brother always wants to play with my phone. He gets very angry when I don't allow it. He owns the computer and television at home. He opens whatever he wants."

\section{a. Violence}

Another problem that typically developing children experience with their siblings with DS is violence. It was determined that the child with DS kicked (P1), spit (P1, P2), pulled his hair (P1, P3), and hit (P1, P2, P3) the typically developing sibling in the house. In addition, typically developing children said that their siblings with DS were stubborn and that they could resort to violence to get what they wanted. Participant 2's opinion on the situation is that; "When my sister doesn't give what she wants, she hits me. She never listens to my mother. If she wants my toy, she will cry until she gets it."

\section{b. Neglect}

Typically developing children with siblings with DS stated that their parents were interested in the sibling with DS and therefore they grew up devoid of interest (P1, P2, P3, P5). Participant 2's opinion on the situation is that; "My mother takes my sister to school every day. She feeds her food. She waits for her at school, she. My mother does not come to my school. My sister is going to Paşaköy. I go to school alone." Participant 3's view on the situation is that; "My mother always takes care of my older brother. Because he has medicines."

\section{c. Inability to Meet Their Needs}

Typically developing children with a sibling with DS stated that they could not meet the needs of their siblings in their home life and therefore they supported both their parents and siblings in this regard (P4, P6, P7, P8, P9, P10). This situation puts more responsibility on the typically developing child than his peers. Participant 7's opinion on the situation is that; "He cannot meet his own needs. In this case, I am helping." Participant 10's opinion on the situation is that; "My brother is smaller and needs attention. He plays with me, eats with me, sleeps with me. We are very overdependent. I'm terrified that something will happen to him." 


\section{d. Health Problems}

Siblings with typically development stated that their siblings with DS were constantly ill and this affected them negatively (P1, P2, P3, P4, P5, P6, P7, P8, P9, P10). In addition, the participants expressed various feelings and concerns about this issue. Participant 3's opinion on this situation is that; "My brother gets sick often. They go to the hospital and stay there. I feel so sorry." Participant 7's opinion on this situation is that; "Because of its low immunity, it is very sensitive in any situation and in any environment. In this respect, we have to be careful all the time. He also has a respiratory problem. This is a situation that demands sensitivity and affects all family members." Participant 5's opinion on this situation is that; "He does not fully explain his health problems. I don't quite understand where it hurts. This makes me sad. Having a health problem is also upsetting." Participant 9's opinion on this situation is that; "My brother has daily medications. We have to follow them constantly. He should not run too much, should not get tired. However, for a man of that age, it is not called running and sitting. That's why he gets sick all the time." Participant 8's opinion on this situation; "He has a problem with his heart, and that's why he's always on heart medication. We follow his movements so that he does not get too tired. He gained a lot of weight because he was sedentary and liked to eat. As he gained weight, we started to encounter different problems. There was a problem with his intestines because he overeating. My brother should be kept under constant control regarding our health problems."

\subsection{Problems Experienced in the School Environment}

Problems experienced by children with typically development with siblings with Down syndrome in the school environment; a) inability to study, b) ridicule were collected in two sub-themes.

\section{a. Inability to Study}

When asked about the hardship experienced in the school environment to the children with a sibling with DS, they stated that their siblings restrained them from studying by tearing their books and notebooks (P1), they ran away with their pencils (P2), so they could not do their homework and their teachers got mad. Participant 2's opinion on this situation is that; "My sister takes my pencils and runs away so that I don't do my homework. If I want to buy it, she either cries or hits me. When I don't do my homework, my teacher gets angry. I know how to read and write. My sister doesn't know, so she doesn't understand."

\section{b. Ridicule}

While 4 of the participants were studying at a different school, 2 of them were attending the same school, and they expressed their sorrow and anger when their other typically developing friends made fun of their siblings with DS. K3's opinion on this situation; "We go to the same school with my brother, but he's in that special subclass. They call my brother and other friends in his class crazy at school. They say you can't learn, you're stupid. I get very angry. How many times have I fought. They're not crazy. My teacher said they only learn slowly." Participant 2's opinion on this situation; "They push my sister during the canteen. She hits them too." 


\subsection{Problems Experienced in the Social Life}

Problems experienced by children with typically development with siblings with DS in the social life; a) game, b) ridicule were collected in two sub-themes.

\section{a. Game}

When typically developing children with DS siblings were asked about the problems experienced in the game environment, they stated that their siblings with DS were excluded in games and they had problems in their ability to comply with the game rules (P1, P2, P5). Participant 1's opinion on this situation; "Everyone is looking at my sister. Children make fun of my sister. I feel sorry. My sister has no friends. My friends don't want to play with him either. My sister is a harpsichord at the game. We can't play games with my sister. She can't run. While I am going out, my sister also wants to go out. When my mother does not send her, she gets very angry and shouts." Participant 5's opinion on this situation; "My sister wants to play in the park. But my friends don't get into their games. My sister goes and watches from afar. She hugs the trees. She is playing with the soil. My sister wants to hug everyone, but my mother gets angry. That's why nobody puts her in the game."

\section{b. Ridicule}

When typically developing children with DS siblings were asked about the problems they experienced in the playground or social life with their siblings with DS, all participants stated that other children mocked their siblings with DS and did not take them into their games, but other people looked after them. Participant 3's opinion on this situation; "My brother loves going out on the streets. When we go out and people look at my brother for a long time, my brother is embarrassed. When they want to talk to my brother, he does not understand him and my brother gets angry. He has no friends. Other children also make fun of my brother as he is crazy. Children threw stones at my brother. His head is split. We go out together. He can't protect himself."

\section{Discussion and Recommendations}

In this study, it was aimed to determine the difficulties experienced by typically developing children with a sibling with DS at home, at school, and in social life. Eleven participants were included in the study and their opinions were received. The first aim of the study is to determine the problems experienced by children with typically development who have a sibling with DS in the home environment. According to the findings of the study, typically developing children with siblings with DS stated that they had problems with the common use of things in the home environment and that their siblings with DS used violence against them. These findings of the study are in line with the research findings of Bagenholm and Gillberg (1991) on sibling relationships of children with intellectual disabilities and autism. In their study, Bagenholm and Gillberg (1991) stated that the special needs siblings of children with typically development have more problem behaviors and they see it as a burden, and they are also worried about their future. In contrast to this research results, some studies indicate that children with 
siblings with DS are more positive and warm, fight less, and are more protective compared to children with siblings with typically development (Orsmond \& Seltzer, 2007; Skotko, Levine \& Goldstein, 2011; Cuskelly \& Gunn, 2003; Fisman et al., 2000; Kaminsky and Dewey, 2002; Hodapp \& Urbano, 2007). In fact, it is stated in various studies that as the dependency levels of siblings with DS increase, the interaction with normally developing siblings increases, and taking more responsibility allows to establish a positive relationship (Cuskelly \& Gunn, 2003; Orsmond \& Seltzer, 2007). In this study, it was also concluded that mothers with children with DS neglect their typically developing children and are more involved in their children with DS. This finding of the study shows similarities with the research findings of Cummings, Bayley, and Rie (1996) describing the effect of the disability status of the children of mothers with disabled children on mothers. Unlike this study, there are also studies in the literature stating that having a sibling with DS does not affect relationships with parents (Orsmond \& Seltzer, 2007; Gözün-Kahraman \& Karaday1, 2015). The main reason why the findings obtained from this research differ from the literature is the focus of the research. The focus of this research is to determine the difficulties that normally developing children face in their relationships with their siblings with DS. For this reason, it is considered acceptable that the findings of the study emphasize the negative situations in sibling relationships.

Another finding of this research is that children with DS have concerns about their health problems and this affects their relationships. Typically developing children stated that their siblings with DS had health problems and therefore they should be followed up continuously, and this situation upset them. Similar to the results of this study, in the study conducted by Graff et al., (2012), the participants stated that their siblings with DS have additional health problems, this is because of their inability. In addition, their siblings with DS cannot live independently due to the fact that they need care and regular follow-up so their family relations are also affected by this.

The second aim of the study is to determine the problems experienced by children with typically development who have siblings with DS in the school environment. When children with a sibling with DS were asked about the problems they experienced in the school environment, they stated that their siblings prevented them from studying and other children made fun of their siblings in the school environment. Gözün-Kahraman and Karadayı (2015) examined the experiences of children with normal development about having siblings with special needs. Some of the study participants stated that they could not study and do what they wanted to do because of their siblings with special needs. In this respect, the findings of the two studies are similar. In addition, the findings of this research; show parallel results with Crnic, Friedrich and Greenberg's (1983) study on the stress levels of families with disabled children and their adaptation to the situation. The final aim of the study is to determine the problems experienced by children with development who have siblings with DS in their social life. When the children with a sibling with DS were asked about the problems they experienced in social life, they stated that they had difficulty playing games with their siblings with DS, that their siblings with DS had no friends and other children made fun of their siblings with DS. Similar to the results of this study, in the study conducted by Gözün-Kahraman and Karadayı (2015), 
some of the children with typically development stated that the problematic behaviors of their siblings with special needs and their inability to play with them negatively affect their. The findings of the study show parallelism with the results of the research conducted by Damiani (1999). As a result of this research, the finding that siblings with DS have problems in games with rules can be accepted as a new result since it has not been found in any source. Unlike the findings of this research, Skotko, Levine, and Goldstein (2011) found that children with typically development; stated that their friends felt comfortable with their siblings with DS, they enjoyed spending time with their siblings with their friends, they were not ashamed of their siblings when they were in public, and their social life was not adversely affected.

Looking at the research findings, it was seen that children with an older sibling with DS complained about the situation and acted reproachfully, while those with a younger sibling with DS were more affectionate and protective. Similar to this study, Fishman et al. (1996), in their study, stated that while older siblings were more warm and protective towards their siblings with DS, younger siblings had more conflicts (act: Fishman ve diğ., 2000). Cuskelly and Gunn (2003) similarly stated that as siblings get older, they take on more responsibilities. In another study, older siblings with typically development stated that having a sibling with DS felt better and their relationship was good, while younger siblings stated that their siblings with DS needed more help and were uncomfortable with this situation (Skotko, Levine, \& Goldstein, 2011). Many factors affect sibling relationships. The age of siblings is one of these factors. It is known that older siblings have more roles and responsibilities in the family than younger siblings. For this reason, older siblings are thought to approach their siblings with DS in a more tolerant, affectionate, and protective way.

Having a child with special needs changes family relationships, daily routines, roles, and responsibilities at home. These changes also affect siblings and relationships between siblings. In this study, it was meant to detect the problems that normally developing children with DS siblings experience in different contexts. As a result of the research that children with typically development experience various problems with their siblings with DS in home, school, and social life, and these problems affect their sibling relationships.

Based on the research findings, it is recommended to carry out studies that will support and strengthen the interactions of typically developing children and siblings with DS. At this point, one of the studies that can be done is to provide information about the diagnoses, developmental characteristics, and appropriate intervention programs of siblings with DS to children with typical development. It is thought that the knowledge of typically developing children about their siblings with DS will positively affect their interactions with their siblings with DS in their home, school, and social lives. Various studies show that informing children with typically development about the diagnosis and characteristics of their siblings enables them to be more interested in their siblings with special needs, to empathize, to develop positive attitudes, and to accept their siblings (Girli, 1995; Küçüker, 1997; Ünal, 2009). 
Another group that needs to be informed at this point is peers with typically development. According to the research findings, individuals with DS are not socially accepted and verbally harassed. For this reason, it is recommended to organize informative activities for the peers of both normally developing siblings and siblings with DS, as well as typically developing siblings. It is thought that positive and accepting attitudes exhibited by peers will reduce the anxiety levels of typically developing children with siblings with DS and contribute to their relations with their siblings.

Finally, the attitudes of the parents also affect the relations of the siblings. It is known that parents get help from siblings in the care of their children with special needs and they impose various responsibilities on siblings at home. It is recommended that families with DS children be provided with the information, social and economic support they need to ensure the balance within the family, to show the parents sufficient attention to their children, and to make the right interventions in case of problems that may arise at home.

\section{Conflict of Interest Statement}

The authors declare no conflicts of interests.

\section{About the Authors}

Burcu Aktaş completed her PhD in Bolu Abant Izzet Baysal University, Special Education Department in 2020. She works as a research assistant in the Special Education Department of Bolu Abant Izzet Baysal University, Turkey.

Mehtap Kot completed her PhD in Bolu Abant Izzet Baysal University, Special Education Department in 2019. She works as an assistant professor in the Special Education Department of Inonü University, Turkey.

İlknur Çifci-Tekinarslan completed her PhD at Ankara University. She works as a professor in the Special Education Department of Bolu Abant Izzet Baysal University, Turkey.

\section{References}

Ahmetoğlu, E. ve Aral, N. (2004). Zihinsel engelli çocukların kardeş ilişkilerinin anne ve kardeş algılarına göre değerlendirilmesi. Yayınlanmamış Doktora Tezi. Ankara Üniversitesi, Fen Bilimleri Enstitüsü, Ankara.

Akkök, F. (2005). Farklı özelliğe sahip çocuk aileleri ve ailelerle yapılan çalışmalar: özel gereksinimli çocuklar. Ataman, A. (Ed. ), Özel Eğitime Giriş. Ankara: Gündüz Eğitim ve Yayıncilik, 121- 142.

Aksoy, A. B. ve Berçin-Yıldırım, G. (2008). Farklı Engel Gruplarından Engelli Kardeşe Sahip Çocukların Kardeş İlişkileri İle Kardeşlerini Kabullenmeleri Arasındaki İlişkinin İncelenmesi. Kuram ve Uygulamada Eğitim Bilimleri, 8 (3), 755-779.

Atasoy, S. (2002). Engelli (otistik) kardeşe sahip olan bireylerin kardeş ilişkilerinin incelenmesi. Yayınlanmamış Uzmanlık Tezi. Ege Üniversitesi, Sosyal Bilimler Enstitüsü, İzmir. 
Bagenholm, A. ve Gillberg, C. (1991). Psychosocial effects on siblings of children with autism and mental retardation: A population- based study. Journal of Mental Deficiency Research, 35(4), 291- 307.

Crnic, K. A., Friedrich, W. N. ve Greenberg, M. T. (1983). Adaptation of families with mentally retarded children : a model of stress, coping and family ecology. American Journal of Mental Deficiency, 88(2), 125-138.

Cummings, S. T., Bayley, H. C. ve Rie, H. E. (1996). Effect of the child's deficiency on the mother: a study of mothers of mentally retarded, chronically ill and neurotic children. American Journal of Orthopsychiatry, 36, 595-608.

Cuskelly, M., \& Gunn, P. (2003). Sibling relationships of children with Down syndrome: Perspectives of mothers, fathers, and siblings. American Journal on Mental Retardation, 108(4), 234-244.

Damiani, B. V. (1999). Responsibility and adjustment in siblings of children with disabilities: update and review. Families in Society: The Journal of Contemporary Human Services, 1, 34-40.

Esenay, F. I., \& Yiğit, R. (2018). Aile fonksiyonları ve disfonksiyonel aile. Türkiye Klinikleri Çocuk Sağlı̆̆ı ve Hastalıkları Hemşireliği-Özel Konular, 4 (2), 102-108.

Eyüboğlu, M., Baykara, B., \& Eyüboğlu, D. (2017). Otizm spektrum bozukluğu olan çocukların sağlıklı gelişim gösteren kardeşlerinin psikososyal özellikler ve yaşam kalitesi açısından değerlendirilmesi. Anatolian Journal of Psychiatry/Anadolu Psikiyatri Dergisi, 18(3).

Fisman, S., Wolf, L., Ellison, D., \& Freeman, T. (2000). A longitudinal study of siblings of children with chronic disabilities. The Canadian Journal of Psychiatry, 45(4), 369375.

Girli, A. (1995). Normal zekalı kardeşlerin zihinsel engelli kardeşe yönelik kabul düzeylerinin belirlenmesi. Yayınlanmamış Yüksek Lisans Tezi. Dokuz Eylül Üniversitesi, Sosyal Bilimler Enstitüsü, İzmir.

Girli, A. (1995). Normal zekâlı kardeşlerin zihinsel engelli kardeşe yönelik kabul düzeylerinin belirlenmesi. Yayımlanmamış Yüksek lisans tezi . Dokuz Eylül Üniversitesi, İzmir.

Gözün-Kahraman, Ö. ve Soylu-Karadayı, N. (2015). Engelli Kardeşe Sahip Olan Çocukların Engelli Kardeşleriyle Deneyimlerine İlişkin Görüşleri. Hacettepe University Faculty of Health Sciences Journal, 1, 390-408.

Graff, C., Mandleco, B., Dyches, T. T., Coverston, C. R., Roper, S. O., \& Freeborn, D. (2012). Perspectives of adolescent siblings of children with Down syndrome who have multiple health problems. Journal of family nursing, 18(2), 175-199.

Hodapp, R. M., \& Urbano, R. C. (2007). Adult siblings of individuals with Down syndrome versus with autism: findings from a large-scale US survey. Journal of Intellectual Disability Research, 51(12), 1018-1029.

Hughes, C., Mcharg, G., \& White, N. (2018) Sibling İnfluences on Prosocial Behavior. Current Opinion In Psychology, 20, 96-101. doi: 10.1016/j.copsyc.2017.08.01

İçöz, A. ve Baran, G. (2001). Zihinsel engelli bir çocuğa sahip aile bireylerinin kayg1 düzeylerinin incelenmesi. Çocuk Gelişimi ve Eğitimi Dergisi, 1(6), 80- 90. 
Kalecik, P. (2013). Otizmli Çocukların Normal Gelişim Gösteren Kardeşlerinin Yaşadıkları Sorunlar. Yayınlanmamış Yüksek Lisans Tezi, Marmara Üniversitesi, Eğitim Bilimleri Enstitüsü, İstanbul.

Kaminsky, L. ve Dewey, D. (2001). Siblings relationships children with autism. Journal of Autism and Developmental Disorders, 31, 399-410.

Kaya, S., Özel, A. \& Yiğit, R. (2020). Özel Gereksinimleri Bulunan Bir Çocuğun Durumunun Kardeşlerine Olan Etkisi. Kırşehir Ahi Evran Üniversitesi Să̆lık Bilimleri Enstitüsü Dergisi, 1 (2), 81-90.

Kızılalp, C. (2018). Kardeşi otizmli olan ve olmayan çocukların kardeş ilişkileri, benlik saygıları ve stresle başa çıkma yolları. Yayınlanmamış Yüksek Lisans Tezi, Maltepe Üniversitesi, Sosyal Bilimler Enstitüsü, İstanbul.

Konuk, R. ve Yıldırım-Doğru, S. (2012). Aile Eğitimi Ve Kardeş Eğitimi Programlarının Kardeşleri Engelli Olan Çocukların Kardeşlerine Yönelik Bilgi ve Beceri Düzeyine Etkisi. Buca Eğitim Fakültesi Dergisi, 33, 135-145.

Küçüker, S. (1997), Bilgi verici psikolojik danışmanlık programının zihinsel özürlü çocukların kardeşlerinin özürle ilgili bilgi düzeylerine ve özürlü kardeşlerine yönelik tutumlarına etkisi. Yüksek Lisans Tezi. Ankara Üniversitesi, Sosyal Bilimler Enstitüsü, Ankara.

Küçüker, S. (1997). Bilgi verici psikolojik danışmanlık programının zihinsel Özürlü çocukların kardeşlerinin özürle ilgili bilgi düzeylerine ve Özürlü kardeşlerine yönelik tutumlarına etkisi. Yayınlanmamış doktora tezi, Ankara Üniversitesi, Ankara.

Merriam, S. B. (2009). Qualitative Research A Guide to Design and Implementation. S. Turan (Çev.). Ankara: Nobel Akademi.

Orsmond, G. I., \& Seltzer, M. M. (2007). Siblings of individuals with autism or Down syndrome: Effects on adult lives. Journal of intellectual disability research, 51(9), 682-696.

Özen-Çınar, İ., Kartal, A. ve Korkmaz-Aslan, G. (2015). Zihinsel Engelli Kardeşi Ve Normal Kardeşi Olan Çocukların Kardeş İlişkileri ve Kendilik Algıları. Halk Sağlığı Etkinlikleri, 18. Ulusal Halk Sağlığı Kongresi, Konya.

Sınanmış, N. ve Kolburan, Ş. G. (2019). Kardeşi Otizmli Olan ve Olmayan Ergenlerin Kardeş İlişkileri ve Sosyal Kaygı Düzeylerinin Karşılaştırılması. Aydın Sağlık Dergisi, 5(1), 13-50.

Skotko, B. G., Levine, S. P., \& Goldstein, R. (2011). Having a brother or sister with Down syndrome: Perspectives from siblings. American Journal of Medical Genetics Part A, 155(10), 2348-2359.

Şafak, P., Eldeniz-Çetin, M. ve Kot, M. (2014). Siblings Attitudes Towards Persons With Severe/Profound And Multiple Disabilities In Turkey. Procedia-Social and Behavioral Sciences 191, 2083-2088.

Şenel, G. H. (1995). Yetersizliğe Sahip Kardeşi Olanlarla, Olmayanların Yetersizliğe Yönelik Tutumları Ve Kaygı Düzeyleri Yönünden Karşılaştırılması. Özel Ĕ̆itim Dergisi, 2(1), 33- 39. 
Şengül Erdem, H., Fazlıŏlu, Y. (2020). Otizm spektrum bozukluğu olan çocukların tipik gelişen kardeşlerinin davranışsal, sosyal ve duygusal özellikleri. Kastamonu Education Journal, 28(4), 1776-1788. doi: 10.24106/kefdergi.4105.

Şengül-Erdem, H., \& Fazlığlu, Y. (2020). Otizm spektrum bozukluğu olan çocukların kardeşlerinin psiko-sosyal özelliklerinin projektif testlerle değerlendirilmesi. Ankara Üniversitesi Eğitim Bilimleri Fakültesi Özel Eğitim Dergisi, 21(3), 537-559. doi: içmeli10.21565/ozelegitimdergisi.601445.

Ünal, N. (2009). Zihinsel engelli çocukların annelerinin çocuk yetiştirme tutumları ile normal gelişim gösteren çocukların zihinsel engelli kardeşlerine yönelik davranışlarının incelenmesi. Yayımlanmamış yüksek lisans tezi, Ankara Üniversitesi, Ankara.

Ünal, N. ve Baran, G. (2011). Zihinsel Engelli Çocukların Annelerinin Çocuk Yetiştirme Tutumları İle Normal Gelişim Gösteren Çocukların Zihinsel Engelli Kardeşlerine Yönelik Davranışları Arasındaki İlişkinin İncelenmesi. Kastamonu Eğitim Dergisi, 3, 783-792.

Yavuzer, H. (2001). Ana- baba ve çocuk (14. Bask1). İstanbul: Remzi Kitabevi.

Yersel, B. Ö., Durualp, E., \& Baran, G. (2019). Tipik gelişim gösteren çocukların işitme engelli kardeşleriyle olan ilişkilerini değerlendirmeye yönelik nitel bir çalışma. Ankara Sağlık Bilimleri Dergisi, 8(2), 107-118.

Yıldırım, A. ve Şimşek, H. (2008). Sosyal Bilimlerde Nitel Araştırma Yöntemleri (7. Baskı). Ankara: Seçkin Yayıncllı.

Zoylan, E. (2005). Engelli kardeşe sahip olan ve olmayan bireylerin kardeş ilişkilerinin belirlenmesi. Yayınlanmamış Yüksek Lisans Tezi. Abant İzzet Baysal Üniversitesi, Bolu. 
Burcu Aktaş, Mehtap Kot, İlknur Çifci-Tekinarslan

PROBLEMS EXPERIENCED BY CHILDREN WITH A SIBLING WITH DOWN SYNDROME

Creative Commons licensing terms

Authors will retain the copyright of their published articles agreeing that a Creative Commons Attribution 4.0 International License (CC BY 4.0) terms will be applied to their work. Under the terms of this license, no permission is required from the author(s) or publisher for members of the community to copy, distribute, transmit or adapt the article content, providing a proper, prominent and unambiguous attribution to the authors in a manner that makes clear that the materials are being reused under permission of a Creative Commons License. Views, opinions and conclusions expressed in this research article are views, opinions and conclusions of the author(s). Open Access Publishing Group and European Journal of Special Education Research shall not be responsible or answerable for any loss, damage or liability caused in relation to/arising out of conflict of interests, copyright violations and inappropriate or inaccurate use of any kind content related or integrated on the research work. All the published works are meeting the Open Access Publishing requirements and can be freely accessed, shared, modified, distributed and used in educational, commercial and non-commercial purposes under a Creative Commons Attribution 4.0 International License (CC BY 4.0). 